\title{
SCHOOL ENTRY IMIMUNISATION CERTIFICATES IN SOUTH WESTERN SYDNEY, 1995
}

Stephen Crone and Laura Baird

South Western Sydney Public Health Unit

This article reports on a review of immunisation certificates (issued under the Public Health Act 1991) in schools in South Western Sydney in 1995.

An amendment to the NSW Public Health Act $1991^{1}$ requires school principals and directors of child care centres to obtain documented evidence of the immunisation status of children enrolling in schools, preschools and child care centres. Parents of children who do not provide documented proof of immunisation are informed that their child may be excluded from school in the event of an outbreak of a vaccine-preventable disease. This requirement came into effect in 1994.

\section{METHOD}

With the approval of regional authorities of the Department of School Education, the South Western Sydney Public Health Unit (SWSPHU) wrote to the principals of all primary schools within the boundaries of the South Western Sydney Area Health Service (SWSAHS) in September 1995 requesting their participation in a review of immunisation records.

The school principals were asked to complete a questionnaire seeking immunisation data on children who were in kindergarten or year 1 in 1995 . These data were obtainable from the immunisation certificates which had (or should have) been collected when the children enrolled, in accordance with the requirements of the Act. For children who had provided an immunisation certificate, the principals were asked to report whether immunisation was recorded complete, incomplete for medical reasons, or incomplete for other reasons. The principals also reported on the number of children for whom no certificate had been provided.

One school was randomly selected from each sector of the SWSAHS for a validation study (six schools altogether). For children in these schools, staff of the SWSPHU compared principals' reports of immunisation data with their own assessments of the immunisation certificates. The immunisation certificate form is reproduced in Figure 1 (page 121). Children were defined as being completely immunised only if all the boxes in Section A of the form were ticked. Certificates with only the 'complete' box ticked were not accepted as evidence of complete immunisation. Small numbers of children had provided other forms of documentation, e.g. photocopies of Personal Health Records and letters from general practitioners; these were not accepted. The validation study was carried out in 1996, and covered children who were in years 1 and 2 at the time (i.e. those who had been in kindergarten and year 1 respectively in 1995).

\section{RESULTS}

The principals of a total of 70 schools (52 per cent of the total number) agreed to participate. These schools represented 7,553 students in 1995 (3,778 in year 1 and 3,775 in kindergarten). Four special purpose primary schools were ineligible to participate because they had no children enrolled in kindergarten or year 1 . None of the schools within one local government area participated.

\begin{tabular}{|lrr|}
\hline \multicolumn{2}{|l|}{ TABLE 4 } & \\
\hline $\begin{array}{l}\text { SCHOOL PRINCIPALS' REPORTS OF IMMUNISATION } \\
\text { CERTIFICATE DATA FOR YEAR 1 CHILDREN, 1995 }\end{array}$ & \\
\hline $\begin{array}{l}\text { Immunisation status } \\
\text { on Certificate }\end{array}$ & $\begin{array}{r}\text { Number of } \\
\text { children }\end{array}$ & Percentage \\
\hline Complete & 3,036 & 80 \\
Incomplete & 190 & 5 \\
Incomplete & & \\
$\quad$ (for medical reasons) & 19 & 0.5 \\
No certificate & 535 & 14 \\
Total & 3,778 & 100 \\
\hline
\end{tabular}

\begin{tabular}{|lrr|}
\hline \multicolumn{2}{|l|}{ TABLE 5} \\
$\begin{array}{l}\text { SCHOOL PRINCIPALS' REPORTS OF IMMUNISATION } \\
\text { CERTIFICATE DATA FOR KINDERGARTEN CHILDREN, }\end{array}$ \\
\hline $\begin{array}{l}\text { Immunisation status } \\
\text { on Certificate }\end{array}$ & $\begin{array}{c}\text { Number of } \\
\text { children }\end{array}$ & Percentage \\
\hline Complete & 3,084 & 82 \\
Incomplete & 201 & 5 \\
Incomplete & & \\
$\quad$ (for medical reasons) & 17 & 0.4 \\
No certificate & 473 & 12 \\
Total & 3,775 & 100 \\
\hline
\end{tabular}

The principals reported that 80 per cent of year 1 and 82 per cent of year 2 children were completely immunised (Tables 4 and 5).

The six schools selected for the validation study represented 721 children who had been enrolled in kindergarten and Year 1 in 1995. However, when the validation was conducted in 1996, only 607 of these children were still enrolled in years 1 and 2 respectively. The loss of 114 children from the sample ( 16 per cent) may have been due to movement of children from one school to another (due to changes of home address).

According to principals' reports, 88 per cent of these 721 children had immunisation certificates showing complete immunisation, with 8 per cent having no certificate. However, staff of the SWSPHU assessed that only 60 per cent had certificates showing complete immunisation, while 30 per cent had no certificates (Table 6).

\section{DISCUSSION}

Our results indicate that school principals in South Western Sydney overestimated the number of kindergarten and year 1 children who had complete immunisation in 1995. Similar findings have been reported from elsewhere in $\mathrm{NSW}^{2}$.

According to school principals, the sample of children involved in the validation study had a higher rate of complete immunisation than those in the 70 schools which participated in the overall survey ( 88 per cent, compared with 80-82 per cent). The validation study was done in 1996 , when only 84 per cent of the original sample (based on 1995 


\section{TABLE 6}

SCHOOL PRINCIPALS' REPORTS OF IMMUNISATION CERTIFICATE DATA FOR YEAR 1 AND YEAR 2 CHILDREN, 1996 COMPARED WITH SWSPHU ASSESSMENT

\begin{tabular}{|lrr|}
\hline $\begin{array}{l}\text { School principal's } \\
\text { assessment of } \\
\text { immunisation status }\end{array}$ & $\begin{array}{r}\text { Number of } \\
\text { children }\end{array}$ & Percentage \\
\hline Complete & 638 & 88 \\
Incomplete & 22 & 3 \\
No certificate & 61 & 8 \\
Total & 721 & 100 \\
\hline SwSPHU & Number of & Percentage \\
assessment of & children & \\
immunisation status & & 60 \\
\hline Complete & 368 & 9 \\
Incomplete & 56 & 30 \\
No certificate & 183 & 100 \\
Total & 607 & \\
\hline
\end{tabular}

enrolments) was available for review. The loss of 114 children from follow-up is likely to reflect migration from school to school; principals reported migration rates ranging from under 5 per cent to almost 40 per cent, with the higher rates tending to occur in areas of high public housing.

Among the 607 children available for the validation study, the SWSPHU found that only 60 per cent had certificates showing complete immunisation, compared with the figure of 88 per cent obtained from school principals. The fact that principals reported only 8 per cent as having no certificate, while SWSPHU found that 30 per cent had no certificate, indicates that principals tended to accept documentation other than the official immunisation certificate form.

Schools in one local government area in the SWSAHS did not respond to the questionnaires. The council had been an active participant in immunisation and had conducted an immunisation review in schools just months before our survey. Principals of the schools in this LGA may have been reluctant to respond to our questionnaire because they had recently provided information for the other survey.

Our results suggest there is a need for the NSW Health Department to work with the Department of School Education to ensure children's immunisation certificates are correctly interpreted.

Despite school principals' problems of interpretation, it appears that correctly interpreted immunisation certificates have the potential for identifying localities with low immunisation rates.

1. NSW Public Health Act 1991.

2. Leckie R, Shah S, Jalaludin B, School entry immunisation certificates: a useful tool for immunisation surveillance? Communicable Diseases Intelligence 1996; 20:6-8.

The NSW Health Department has had discussions with the Department of School Education about practical aspects of implementation of the immunisation provisions of the Public Health Act 1991. These discussions will continue in the light of the Health Department's proposed 1997 evaluation of compliance with the immunisation provisions.

\section{Administration of immunisation provisions}

\section{Continued from page 120}

For comparison, the 1995 Australian Bureau of Statistics survey Children's Immunisation Australia found that 94 per cent of five-year-old children were immunised against measles and 68 per cent against pertussis ${ }^{5}$.

Telephone and site interviews with school staff revealed difficulties faced by schools and parents. There was some misunderstanding of issues surrounding the Act, including notification requirements for vaccine-preventable diseases and exclusion procedures. In relation to documentation, some schools were not clear about their obligation to collect official immunisation certificates and the role of general practitioners as the main providers of certificates. A major finding of this and other surveys has been the reliance by some schools on documents other than the official certificates, and the large number of certificates which was completed incorrectly ${ }^{24}$. Despite insufficient expertise, school staff felt obliged to interpret these documents. As a consequence, school records of immunisation status are likely to contain some inaccuracies.

\section{CONCLUSIONS}

The value of immunisation certificates as reminders to parents is clear. Sole reliance on the certificates as an accurate source of information on immunisation coverage and status during an outbreak would require strategies to increase understanding and cooperation among schools and immunisation providers. Such strategies might include simplifying the certificate form, providing certificates to schools for distribution to parents, and further education of parents, providers and primary school staff on the rationale and requirements of the Act.

\section{ACKNOWLEDGMENTS}

We acknowledge the thoughtful assistance of all school staff involved in the survey.

1. Ferson MJ. Census of school entry immunisation certificates, Eastern Sydney, 1994 NSW Public Health Bulletin 1995; 2:9-10.

2. Watt PD. An evaluation of 1994 school entry immunisation certificates on the Central Coast of New South Wales. J Paediatr Child. Health 1996; 32:125-131

3. Rixon G, Hort K, Liddle J. School entry certificate survey, Northern Sydney Area. NSW Public Health Bulletin 1994; 5:92.

4. Leckie R, Shah S, Jalaludin B. School entry immunisation certificates: A useful tool for immunisation surveillance? Communicable Diseases Intelligence 1996; 20:6-8

5. Australian Bureau of Statistics. Children's immunisation Australia, April 1995. (Cat No 4352.0) Canberra: Australian Bureau of Statistics, 1996. 